\title{
Perancangan Sistem Informasi Administrasi Surat Berbasis Desktop Pada Kantor Notaris Hoiril Masuli, Sh, M.Kn
}

\author{
Agus Dendi Rachmatsyah ${ }^{[1]}$, Datia Merlini ${ }^{[2]}$ \\ STMIK Atma Luhur, Jl. Jend. Sudirman, Selindung, Pangkalpinang, Kep. Bangka Belitung \\ Program Studi Sistem Informasi ${ }^{[1][2]}$ \\ dendi@atmaluhur.ac.id ${ }^{[1]}, 1322500064 @$ mahasiswa.atmaluhur.ac.id ${ }^{[2]}$
}

\begin{abstract}
Abstrak - Pada Kantor Notaris Hoiril Masuli, Sh, M.Kn dalam pengelolaan penerimaan berkas masih menggunakan cara manual dan belum terkomputerisasi. Hal ini meyulitkan pegawai dalam pengelolaan data klien, seperti halnya dalam penyimpanan data-data yang masih disimpan dalam bentuk berkas sehingga menyulitkan pegawai dalam mencari data berkas masuk dari klien ataupun berkas yang sudah selesai dibuat serta berkas yang sudah diambil klien. Untuk mengatasi masalah-masalah yang dihadapi, untuk mempercepat pekerjaan dan memudahkan pengelolahaan data perlu adanya sistem yang terkomputerisasi dalam pengelolaan berkas klien. Pada penelitian ini metode yang digunakan adalah berorientasi objek, model penelitian yang digunakan adalah Waterfall serta tools yang digunakan adalah UML (Unified Model Language).
\end{abstract}

Kata Kunci-Sistem Informasi, Notaris, Administrasi, Surat Menyurat

\section{PENDAhuluan}

Berdasarkan bunyi pasal 1 Peraturan Jabatan Notaris (Staatsblad 1860 Nomor 3) bahwa yang dimaksud dengan Notaris adalah pejabat umum yang satu-satunya berwenang untuk membuat akta otentik mengenai semua pembuatan, perjanjian, dan penetapan yang diharuskan oleh suatu peraturan umum atau oleh yang berkepentingan dikehendaki untuk dinyatakan dalam suatu akta otentik, menjamin kepastian tanggalnya, menyimpan aktanya dan memberikan grosse, salinan dan kutipannya, semuanya sepanjang pembuatan akta itu oleh suatu peraturan umum tidak juga ditugaskan atau dikecualikan kepada pejabat atau orang lain. Sedangkan yang dimaksud dengan Akta Otentik sebagaimana yang diatur dalam pasal 1868 Kitab Undang-Undang Hukum Perdata adalah suatu akta yang sedemikian, yang dibuat dalam bentuk yang ditentukan oleh undang - undang oleh atau di hadapan pejabat umum yang berwenang untuk itu, di tempat di mana akta itu dibuat. Keberhasilan seorang Notaris tidak hanya bisa diukur dari banyaknya akta yang ia buat, melainkan juga dari kepiawaiannya mengatur administrasi di kantornya. Akta yang banyak, tanpa disertai administrasi yang rapi dan teratur akan mengakibatkan masalah dan kesulitan dikemudian hari.

Oleh karena itu perlu bagi seorang calon Notaris untuk mengetahui, mempelajari serta memperhatikan administrasi kantor, sebelum ia melaksanakan jabatannya sebagai seorang
Notaris. Di kantor Notaris dalam pengelolaan penerimaan berkas masih menggunakan cara manual dan belum terkomputerisasi. Hal ini meyulitkan pegawai dalam pengelolaan data klien, seperti halnya dalam penyimpanan data-data yang masih disimpan dalam bentuk berkas sehingga menyulitkan pegawai dalam mencari data berkas masuk dari klien ataupun berkas yang sudah selesai dibuat serta berkas yang sudah diambil klien.

Untuk mengatasi masalah-masalah yang dihadapi, untuk mempercepat pekerjaan dan memudahkan pengelolahaan data perlu adanya sistem yang terkomputerisasi dalam pengelolaan berkas klien. Oleh karena itu penulis akan melakukan penelitian dengan judul "Perancangan Sistem Informasi Administrasi Surat Berbasis Desktop Pada Kantor Notaris Hoiril Masuli, Sh, M.Kn".

\section{LANDASAN TEORI}

\section{A. Konsep Dasar Sistem Informasi}

Menyangkut pemahaman tentang pengertian sistem informasi ini, dalam bukunya Agus Mulyanto mengutipkan beberapa pendapat para ahli [1], diantaranya:

- Menurut James alter, sistem informasi adalah "kombinasi antar prosedur kerja, informasi, orang dan teknologi informasi yang diorganisasikan untuk mencapai tujuan dalam sebuah organisasi”.

- Menurut Bodnar dan Hopwood, sistem informasi adalah "kumpulan perangkat keras dan perangkat lunak yang dirancang untuk mentransformasikan data ke dalam bentuk informasi yang berguna".

\section{B. Model Pengembangan Sistem}

Menurut Pressman (2015:42), model waterfall adalah model klasik yang bersifat sistematis, berurutan dalam membangun software. Nama model ini sebenarnya adalah "Linear Sequential Model". Model ini sering disebut juga dengan "classic life cycle" atau metode waterfall. Model ini termasuk ke dalam model generic pada rekayasa perangkat lunak dan pertama kali diperkenalkan oleh Winston Royce sekitar tahun 1970 sehingga sering dianggap kuno, tetapi 
merupakan model yang paling banyak dipakai dalam Software Engineering (SE). Model ini melakukan pendekatan secara sistematis dan berurutan. Disebut dengan waterfall karena tahap demi tahap yang dilalui

harus menunggu selesainya tahap sebelumnya dan berjalan berurutan. Model waterfall adalah model klasik yang bersifat sistematis, berurutan dalam membangun software. Nama model ini sebenarnya adalah "Linear Sequential Model".

\section{Metode Penelitian}

\section{1) Analisa Berorientasi Objek}

Pengertian Berorientasi Objek menurut Sholiq (2010:1) pada buku karangannya Analisis dan Perancangan Berorientasi Obyek : “ Berorientasi obyek atau object oriented merupakan paradigma. Paradigma ini memandang sistem sebagai kumpulan obyek-obyek diskrit yang saling beriteraksi satu sama lain. Berorientasi obyek ini juga bermakna kegiatan mengorganisasikan perangkat lunak sebagai kumpulan-kumpulan obyek diskrit yang bekerja sama antara informasi (struktur data) dan perilaku yang mengaturnya" [4].

\section{2) Perancangan Berorientasi Objek}

Perancangan berorientasi objek adalah proses spesifikasi yang terperinci atau pendefinisian dari kebutuhan-kebutuhan fungsional dan persiapan untuk rancang bangun implementasi yang menggambarkan bagaimana suatu sistem dibentuk. Untuk mengembangkan suatu sistem baru dilakukan dengan menguraikan hubungan proses-proses dalam bentuk diagram-diagram.

\section{Pengertian Administrasi}

Pada dasaranya administrasi melingkupi seluruh kegiatan dari pengaturan hingga pengurusan sekelompok orang yang memiliki diferensiasi pekerjaan untuk mencapai suatu tujuan bersama. Administrasi dapat berjalan dengan adanya banyak orang terlibat di dalamnya. Hal ini sesuai dengan pengertian administrasi yang dapat dibedakan menjadi dua bagian yang dikemukakan oleh Irra Chisyanti Dewi (2011:3) dalam buku Pengantar Ilmu Administrasi.

\section{E. Pengertian Surat Menyurat}

Surat merupakan alat atau sarana untuk menyampaikan pernyataan atau informasi secara tertulis dari pihak satu kepada pihak lainnya. Informasi tersebut dapat berupa pemberitahuan, pernyataan, permintaan, laporan, sanggahan, pemikiran, pertanyaan, dan sebagainya. Surat sering digunakan oleh perusahaan atau organisasi karena surat berperan sebagai alat pengingat dan sebagai bahan dokumentasi bagi setiap proses baik internal maupun eksternal [9].

\section{F. Visual Basic 2008}

Visual Basic merupakan bahasa pemprograman yang dikembangkan dari bahasa pemrograman Basic. Bahasa pemprogramanbasic merupakan bahasa pemprograman yang sangat populer, dikembangkan dari tahun 1963. Akronim dari
BASIC adalah Beninner's All Purpose Symbolic Instruction Code.Dengan akronim tersebut, dapat kita mengerti bahasa basic merupakan bahasa bagi pemula, mudah, dan handal untuk semua tujuan. Visual Basic merupakan bahasa yang dikembangkandari basic yang ditujukan untuk membuat program cepat dengan tampilanGUI (Graphical User Interface). Istilah ini sering disebut dengan RAD (Rapid Application Development).

\section{G. Microsoft Access 2007}

Microsoft Acess 2007 adalah sebuah program aplikasi basis data komputer relasional yang ditunjukan untuk kalangan rumahan dan perusahaan kecil hingga menengah, dan juga menggunakan tampilan grafis yang intuitif sehingga memudahkan pengguna. Database adalah kumpulan tabeltabel yang saling berelasi. Antar tabel yang satu dengan yang lain saling berelasi, sehingga sering disebut basis data relasional. Relasi antar tabel dihubungkan oleh suatu key, yaitu primary key dan foreign key [11].

\section{Metodologi PENELITIAN}

\section{A. Model Pengembangan Sistem}

Sistem yang akan dibangun dalam Analisa Dan Perancangan Sistem Administrasi Surat Berbasis Desktop Pada Kantor Notaris Hoiril Masuli, Sh, M.Kn itu sendiri User akan menggunakan media yang terkomputerisasi, karena untuk memanfaatkan fasilitas tersebut data-data yang dimiliki akan disimpan kedalam database.

Desain penelitian ini dimodelkan dengan menggunakan model proses Waterfall, merupakan model pengembangan perangkat lunak yang sistematik dan sekuensial yang mulai pada tingkat dan kemajuan sistem sampai pada analisis, desain, kode, test, dan pemeliharaan. Dari pengertian metode waterfall diatas penulis akan memberikan beberapa alasan mengapa penulis menggunakan metode pengembangan sistem dengan waterfall, yaitu dikarenakan penulis akan lebih mudah dalam merancang sistem yang diinginkan dan dapat diterima oleh user sebagai pemakai, penulis menginginkan perancangan sistem yang telah dihasilkan kemudian dipersentasikan kepada user dan user diberikan kesempatan untuk diberikan masukanmasukan sehingga sistem informasi yang dihasilkan betulbetul sesuai dengan yang diinginkan.

\section{B. Metode Berorientasi Objek}

Pada penelitian ini metode yang digunakan metode berorientasi objek. Tujuan dari penggunaan metode berorientasi objek adalah untuk mengidentifikasikan semua atribut data yang dibutuhkan oleh sistem yang dibangun. Yang berorientasi proses dikerjakan dengan memeriksa semua input, output dan proses untuk sistem. Berdasarkan karakteristiknya keunggulan pendekatan objek adalah dapat meningkatkan efisiensi aplikasi karena sifatnya yang dapat diwariskan (digunakan kembali untuk objek lainnya) khususnya untuk sistem yang besar dan kompleks, selain itu karena model yang dinamis model ini tepat untuk sistem yang real time. Selain itu 
dalam dunia pemrograman konsep objek ini telah digunakan secara luas terbukti dengan banyaknya bahasa pemrogram yang berbasis objek.

\section{Tools Yang Digunakan}

Pada tahap perancangan perangkat lunak ini penulis menggunakan pendekatan berorientasi objek dimana dalam pendekatan ini dilengkapi dengan alat-alat (tools) dan teknikteknik yang dibutuhkan dalam pengembangan sistem, serta hasil dari sistem yang dikembangkan akan didapatkan sistem yang strukturnya didefinisikan dengan baik dan jelas. Tools yang digunakan pada tahap ini adalah UML (Unified Modelling Language) sebagai bahasa pemodelan untuk menjelaskan dan memvisualisasikan proses analisis dan perancangan sistem.

\section{HASIL DAN PEMBAHASAN}

\section{A. Analisa dan perancangan Sistem}

\section{1) Analisa Proses Bisnis}

Prosedur pengarsipan surat menyurat dari sistem yang sedang berjalan dapat dilihat dalam bagan aliran dokumen, penggambaran ini lebih menekankan pada pengaliran dokumen atau data-data pendukung yang digunakan dari satu bagian ke bagian lainnya. Adapun uraian prosedurnya, sebagai berikut :

\section{a) Proses Pendataan Pegawai}

Asisten notaris mencatat data pegawai, kemudian diserahkan kebagian administrasi untuk diarsipkan dilemari arsip.

\section{b) Proses Pendataan Klien}

Bagian Administrasi mencatat data Klien yang diterima dari klien, kemudian bagian administrasi mengarsipkan data klien dilemari arsip.

\section{c) Proses Surat Keluar}

Asisten Notaris memberikan draf surat keluar yang akan dibuat oleh bagian administrasi, setelah itu surat diberikan kepada Notaris untuk di periksa dan memberi persetujuan. Jika surat tidak disetujui maka draf surat dikembalikan ke Asisten Notaris, dan jika disetujui bagian administrasi membubuhkan cap. Setelah itu bagian administrasi akan mengirimkan surat tersebut kepada penerima.

\section{d) Proses Surat Masuk}

Pengirim mengirim surat masuk ke Notaris dan diterima oleh bagian administrasi. Setelah itu bagian administrasi akan memberi Acc bukti surat masuk. Kemudian bagian administrasi mencatat dibukti tanda terima surat, yang akan diberikan kepada Notaris beserta dengan surat masuknya. Notaris membaca surat masuk tersebut, setelah membaca surat masuk notaris meberikan surat masuk tersebut ke asisten notaris dan kemudian menyerahkannya ke bagian administrasi. Bagian administrasi akan mengklarifikasi surat masuk, dan kemudian mengarsipkannya.

\section{e) Proses Surat Pengantar Wasiat}

Bagian administrasi membuat surat pengantar wasiat sesuai data bulanan yang ada, setelah itu surat pengantar wasiat diserahkankan kepada asisten notaris untuk diberikan kepala notaris. Notaris menerima surat pengantar wasiat yang kemudian ditandatangani dan diberikan kembali ke asisten notaris. Kemudian asisten notaris memberikan surat pengantar wasiat untuk dikirimkan beserta lampirannya kepada instansi penerima.

\section{f) Proses Surat Pengantar Akta}

Bagian administrasi membuat surat pengantar akta sesuai data bulanan yang ada, setelah itu surat pengantar akta diserahkankan kepada asisten notaris untuk diberikan kepala notaris. Notaris menerima surat pengantar akta yang kemudian ditandatangani dan diberikan kembali ke asisten notaris. Kemudian asisten notaris memberikan surat pengantar akta untuk dikirimkan beserta lampirannya kepada instansi penerima.

\section{g) Proses Pendataan Akta}

Bagian administrasi mencatatat data Akta sesuai dengan data yang ada, setelah itu data tersebut diserahkan ke bagian asisten notaris yang kemudian akan diperiksa oleh Notaris. Setelah diperiksa oleh notaris dan di acc maka data diserahkan kembali ke bagian administrasi untuk dikirimkan ke instansi Penerima. Bagian administrasi meminta bukti penerimaan laporan ke bagian sekretaris instansi Penerima.

\section{h) Proses Pendataan Wasiat}

Bagian administrasi mencatatat data Wasiat sesuai dengan data yang ada, setelah itu data tersebut diserahkan ke bagian asisten notaris yang kemudian akan diperiksa oleh Notaris. Setelah diperiksa oleh notaris dan di acc maka data diserahkan kembali ke bagian administrasi untuk dikirimkan ke Kantor Penerima. Bagian administrasi meminta bukti penerimaan laporan ke bagian sekretaris instansi Penerima.

\section{i) Proses Pembuatan Laporan Bulanan Akta}

Bagian administrasi membuat laporan bulanan akta, kemudian menyerahkan laporan bulanan akta tersebut kepada asisten notaris untuk diberikan kepada Notaris agar ditandatangani, setelah itu laporan yang sudah ditandatangani diberikan kepada asisten notaris untuk diberikan kepada bagian administrasi dan dikirimkan ke instansi penerima.

\section{j) Proses Pembuatan Laporan Bulanan Wasiat}

Bagian administrasi membuat laporan bulanan wasiat, kemudian menyerahkan laporan bulanan wasiat tersebut kepada asisten notaris untuk diberikan kepada Notaris agar ditandatangani, setelah itu laporan yang sudah ditandatangani diberikan kepada asisten notaris untuk diberikan kepada bagian administrasi dan dikirimkan ke instansi penerima. 
B. Usecase Diagram

1) Use Case Diagram Master

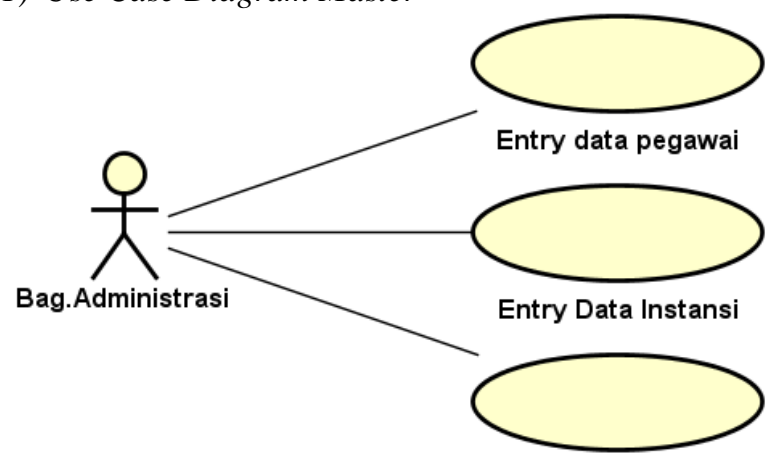

Entry Data Klien Gambar 1. Use Case Diagram Master

2) Use Case Diagram Surat Masuk

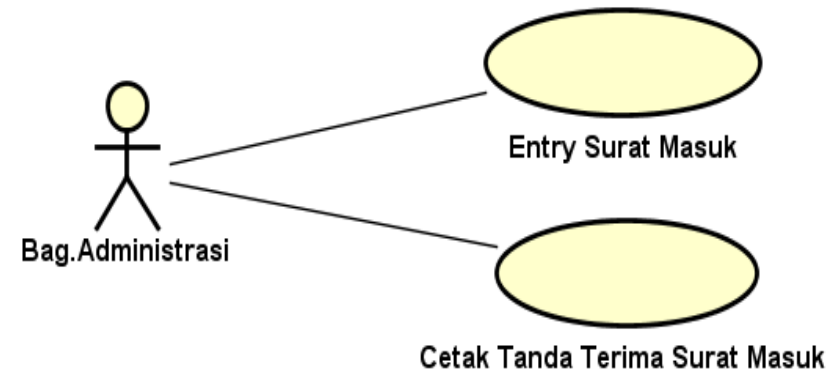

Gambar 2. Use Case Diagram Surat Masuk

3) Use Case Diagram Surat Keluar

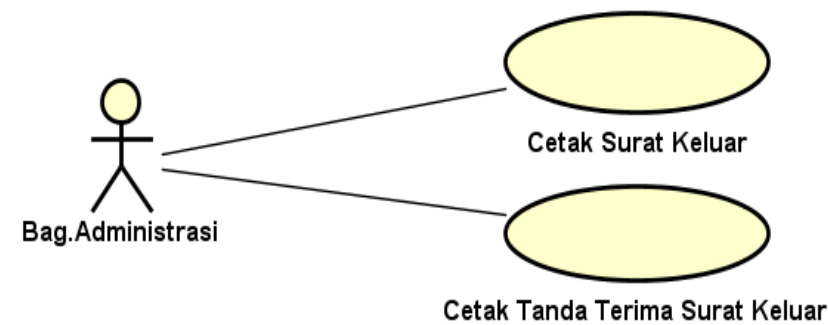

Gambar 3. Use Case Diagram Surat Keluar

4) Use Case Diagram Wasiat

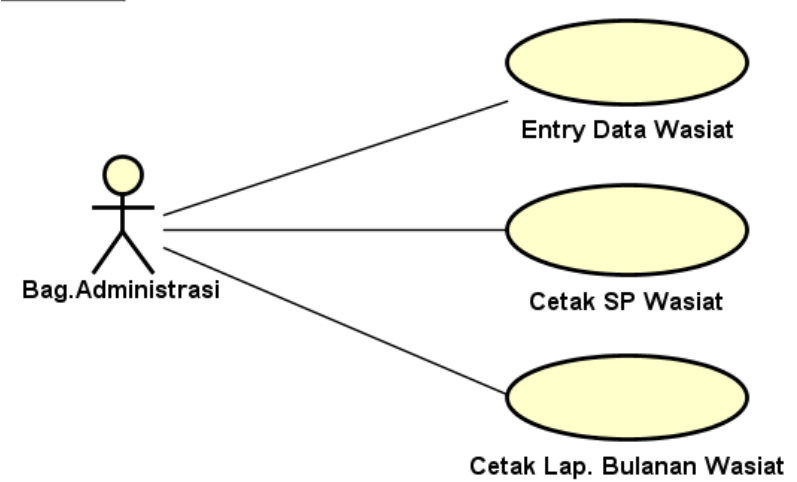

Gambar 4. Use Case Diagram Wasiat
5) Use Case Diagram Akta

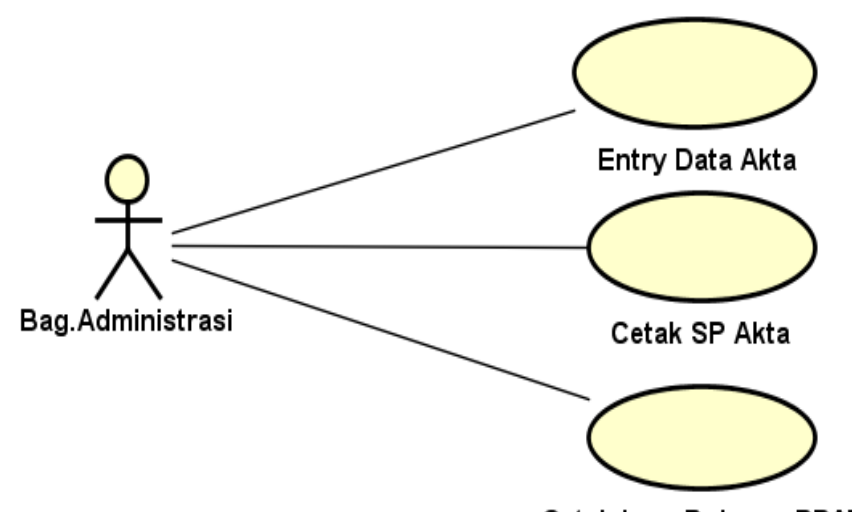

Cetak Lap. Bulanan PPAT

Gambar 5. Use Case Diagram Akta

C. Rancangan Basis Data

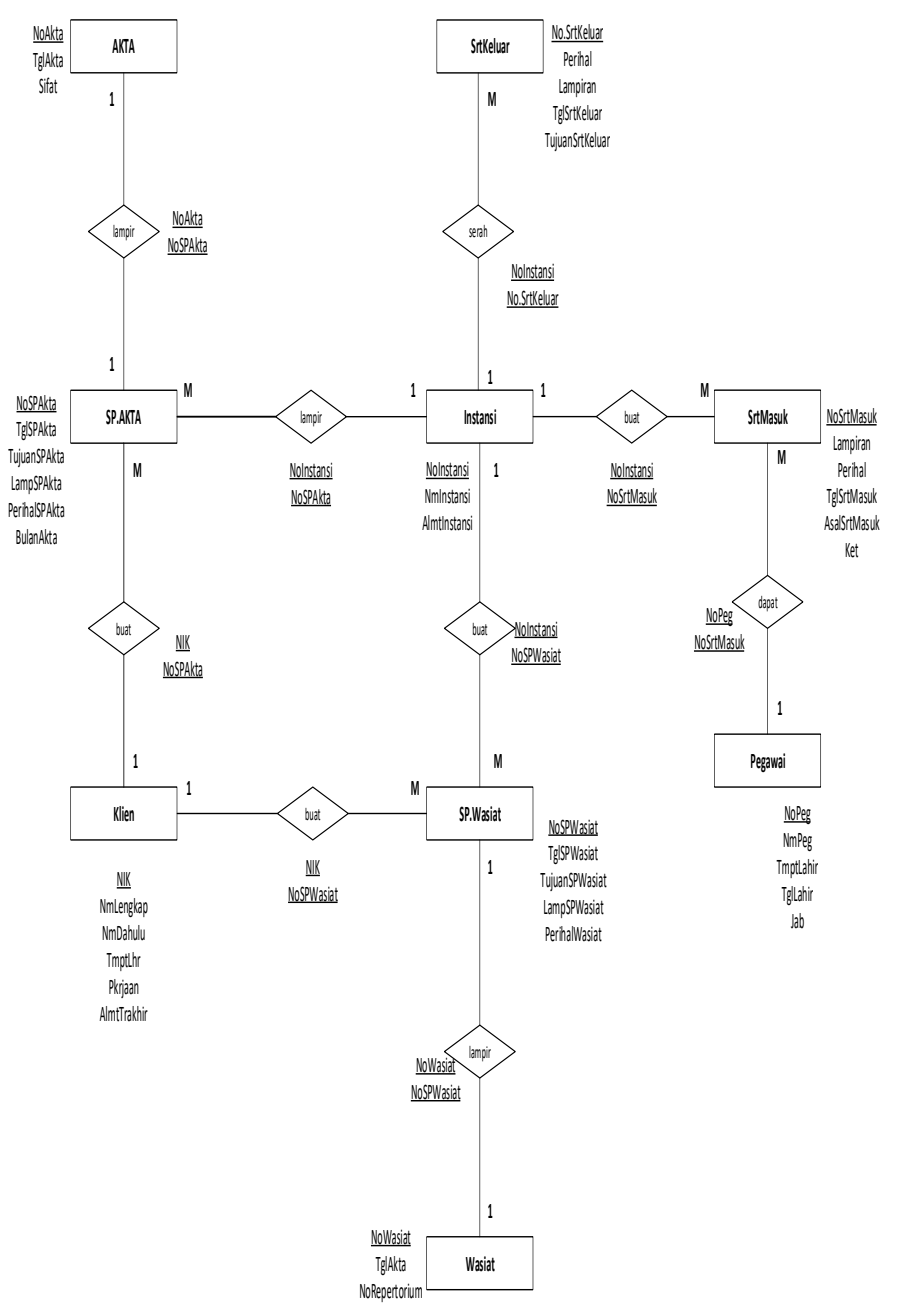


Jurnal SISFOKOM, Volume 06, Nomor 02, September 2017

D. Rancangan Dialog Layar

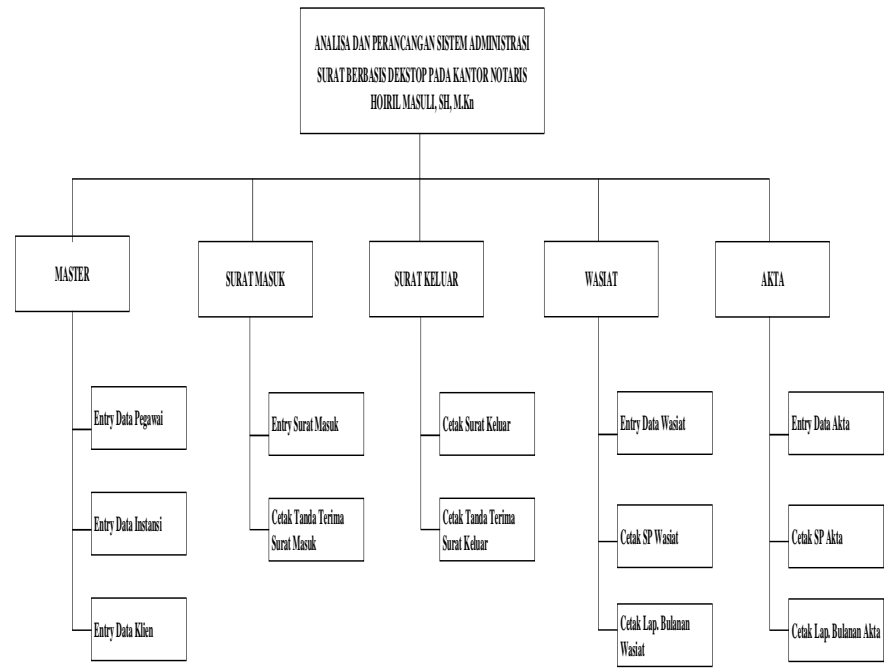

Gambar 7. Rancangan Dialog Layar

E. Rancangan Layar

1) Rancangan Layar Master

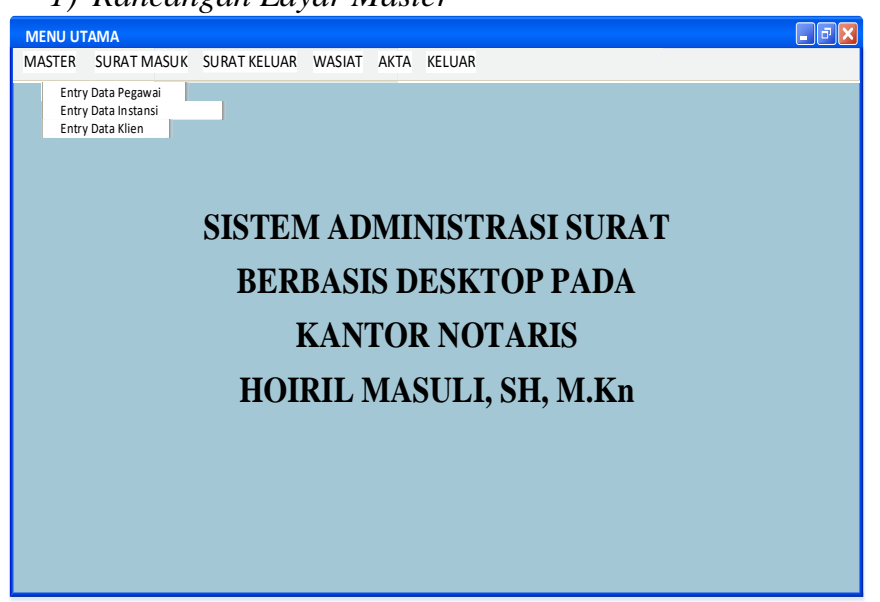

Gambar 8. Rancangan Layar Master

2) Rancangan Layar Menu Surat Masuk

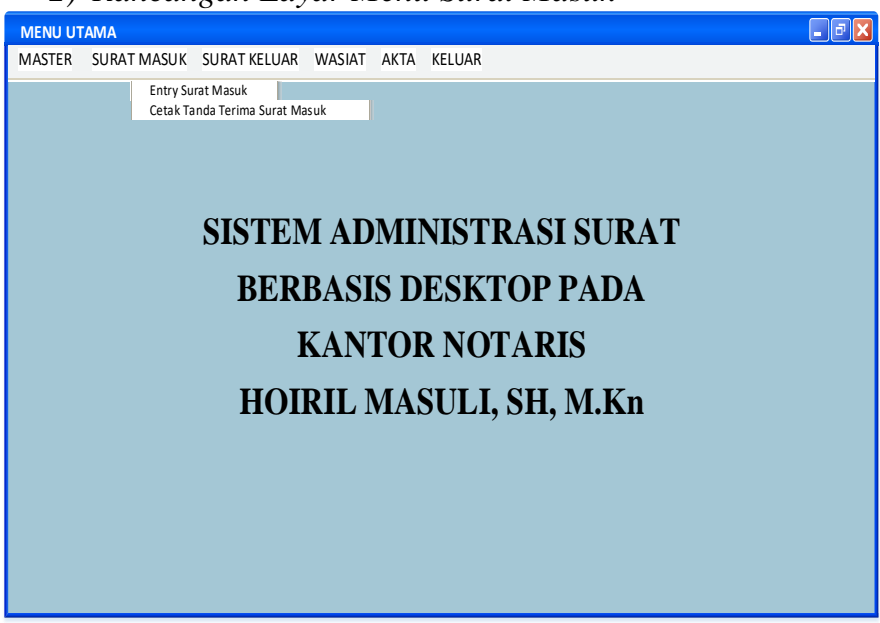

Gambar 9. Rancangan Layar Menu Surat Masuk

\section{3) Rancangan Layar Menu Surat Keluar}

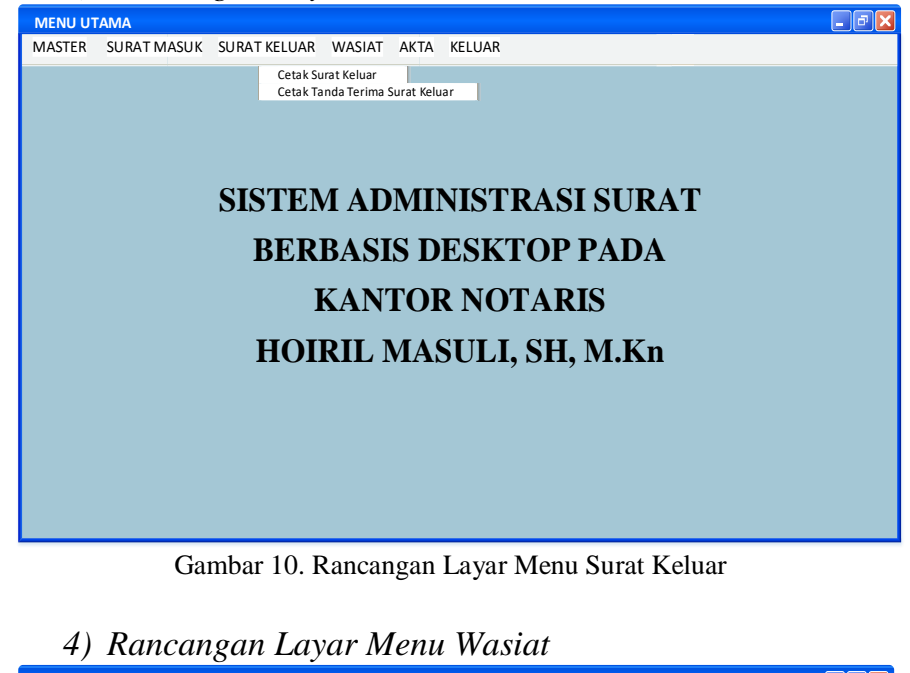

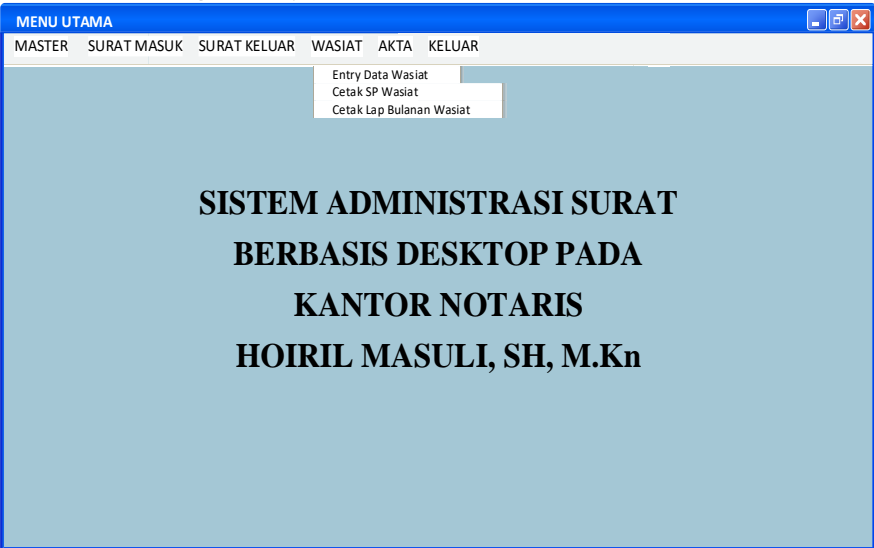

Gambar 11. Rancangan Layar Menu Wasiat

5) Rancangan Layar Menu Akta

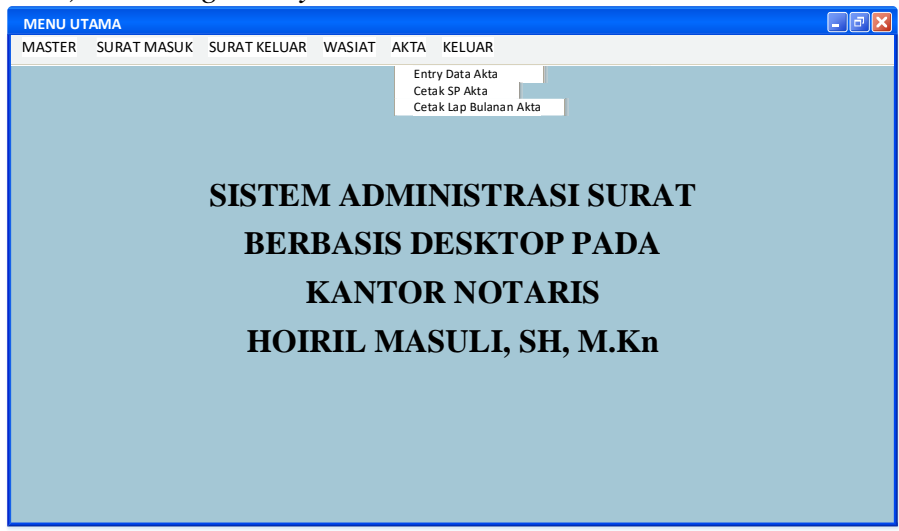

Gambar 12. Rancangan Layar Menu Akta

\section{F. Sequence Diagram}

1) Sequence Diagram Entry Data Pegawai 


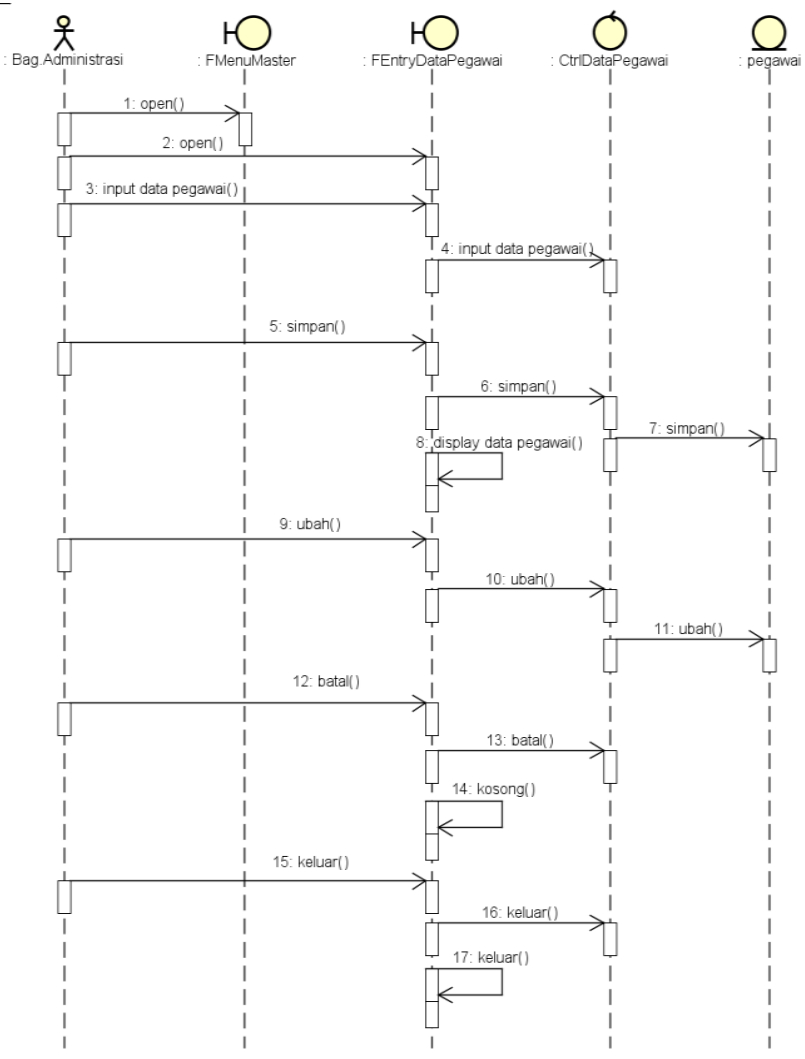

Gambar 13. Sequence Diagram Entry Data Pegawai

\section{2) Sequence Diagram Entry Surat Masuk}

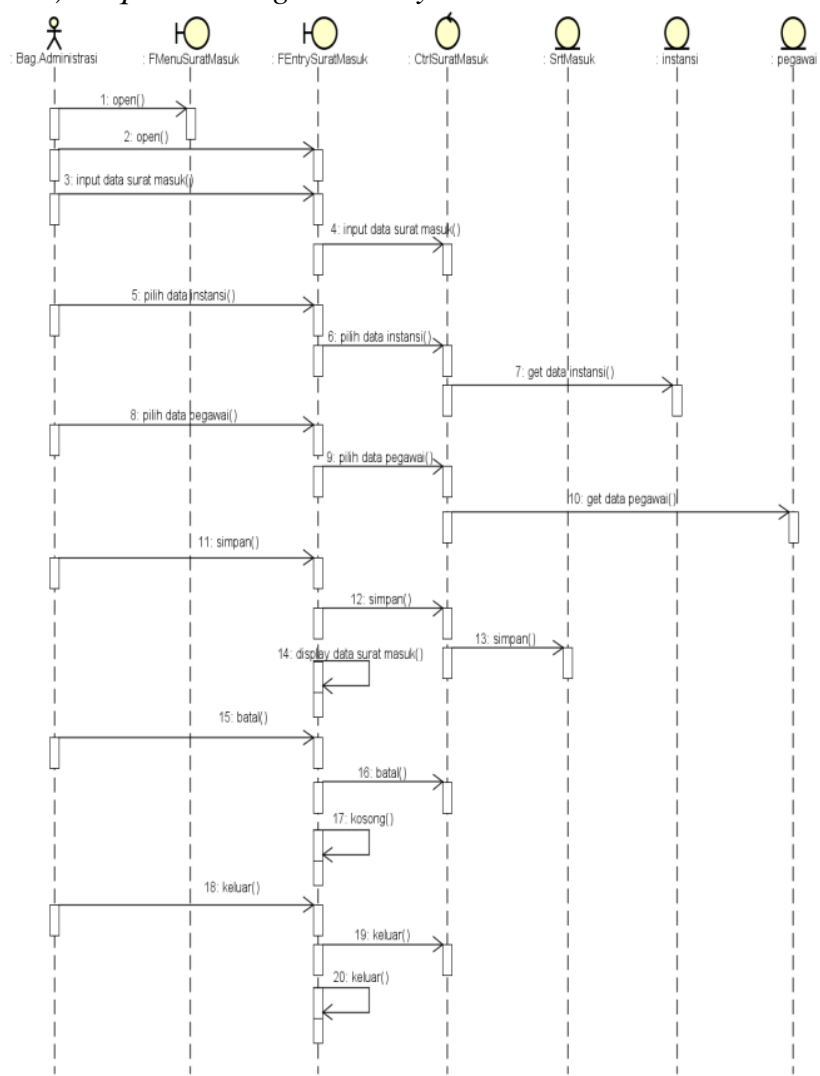

Gambar 14. Sequence Diagram Entry Surat Masuk
3) Sequence Diagram Cetak Tanda Terima Surat Masuk

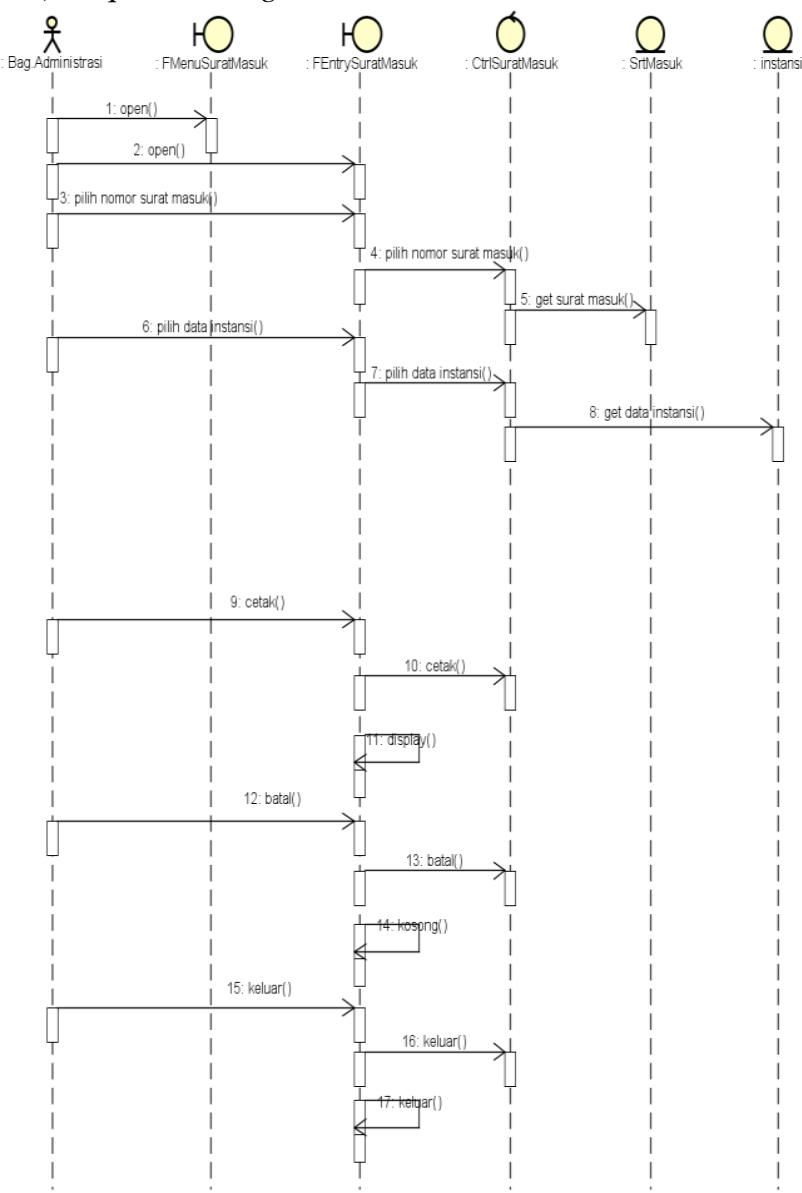

Gambar 15. Sequence Diagram Cetak Tanda Terima Surat Masuk

\section{Penutup}

\section{A. Kesimpulan}

Beberapa kesimpulan yang dapar diambil dari Sistem yang diusulkan dapat memberikan layanan sebagai berikut:

- Dengan sistem yang terkomputerisasi maka dapat mengurangi kesalahan dalam pengelolaan surat Pada Kantor Notaris Hoiril Masuli, Sh, M.Kn.

- Meningkatkan efisiensi kerja karena proses pembuatan laporan dengan Sistem disajikan lebih cepat dan akurat apabila sewaktu - waktu dibutuhkan.

\section{B. Saran}

Agar proses Administrasi Surat Pada Kantor Notaris Hoiril Masuli, Sh, M.Kn dapat berjalan dengan baik sesuai yang diinginkan akan tercapai maka disarankan :

- Perlunya ada back up data guna mencegah hal - hal yang tidak diinginkan

- Masih banyak fasilitas lain yang dapat dikembangkan dalam sistem Administrasi Surat Pada Kantor Notaris Hoiril Masuli, Sh, M.Kn yang telah dibuat ini, yang mana pengembangan tersebut dapat meningkatkan mutu dan kualitas yang lebih baik 


\section{DAFTAR PUSTAKA}

[1] Agus, Mulyanto. 2009:29. Sistem Informasi Konsep dan Aplikasi. Pustaka Pelajar : Yogyakarta.

[2] Pressman, R.S. 2015. Rekayasa Perangkat Lunak: Pendekatan Praktisi Buku I. Yogyakarta: Andi

[3] Sugiyono, 2013:2, Metode Penelitian Kuantitatif, Kualitatif dan R\&D. Alfabeta, Bandung.

[4] Sholiq, 2010, Analisis dan Perancangan Berorientasi Objek, Muria Indah, Bandung.

[5] Satzinger, W, J., Jackson, B, R., dan Burd, D, S. 2009. Systems Analysis and Design In A Changing World. Boston: Cengage Learning.

[6] Sutanta, Edhy. Basis Data dalam Tinjauan Konseptual. Yogyakarta: Andi, 2011.

[7] Booch, G., Maksimchuk, R. A., Engle, M. W., Young, B. J., Conallen, J., \& Houston, K. A. (2007), Object Oriented Analysis and Design with Applications Third Edition. Westford, Massachussets: Addison-Wesley.
[8] Dewi, Irra Chrisyanti. 2011. Pengantar Ilmu Administrasi, PT Prestasi Pustakaraya. Jakarta.

[9] http://bahasa.kemdiknas.go.id/kbbi/index.php, diakses pada tanggal 26 April 2017.

[10] Rahmat Priyanto. 2009. LANGSUNG BISA VISUAL BASIC.NET 2008, Jakarta : Andi Publisher.

[11] Handoko Budisetyo. 2007.Panduan Lengkap Microsoft Access 2007, Jakarta : Andi Publisher.

[12] Kurnia Adhi Saputra dan Muga Linggar Famukhit, 2014, Perancangan Sistem Informasi Pengelolaan Surat Masuk Dan Surat Keluar Pada MTs Guppi Jetiskidul, Universitas Yudharta Pasuruan, Pasuruan.

[13] Rizki Maulana Syaban dan H. Bunyamin, 2015, Pengembangan Sistem Informasi Pengelolaan Surat Masuk Dan Surat Keluar Berbasis Web D Dinas Sosial Tenaga Kerja Dan Transmigrasi Kabupaten Garut Menggunakan Framework Php, Sekolah Tinggi Teknologi Garut, Garut

[14] Luthfi Muhammad Iqbal, 2016, Sistem Informasi Administrasi Surat Masuk dan Surat Keluar Pada Sekolah Dasar Negeri Bojong, Universitas Komputer, Bandung. 